January 1957

\title{
Tax Policy for Economic Growth
}

Wilbur D. Mills

\section{Recommended Citation}

Wilbur D. Mills, Tax Policy for Economic Growth, 11 Sw L.J. 27 (1957)

https://scholar.smu.edu/smulr/vol11/iss1/2

This Article is brought to you for free and open access by the Law Journals at SMU Scholar. It has been accepted for inclusion in SMU Law Review by an authorized administrator of SMU Scholar. For more information, please visit http://digitalrepository.smu.edu. 


\title{
TAX POLICY FOR ECONOMIC GROWTH ${ }^{\dagger}$
}

\author{
by \\ Wilbur D. Mills*
}

$\mathrm{O}$ $\mathrm{N}$ July 10, 1956, the Committee on Ways and Means authorized the establishment of a Subcommittee on Internal Revenue Taxation. The Subcommittee was established for the purpose of investigating and studying the operation and effects of the internal revenue laws of the United States as to substantive policy, technical adequacy and administration, and making recommendations with respect thereto. The jurisdiction of the Subcommittee is as broad as the jurisdiction of the Committee on Ways and Means in tax matters, with the exception of excise taxes.

Before outlining the scope of the Subcommittee's undertaking, let us examine some of the background facts leading to its establishment.

On August 16, 1954, H. R. 8300 was signed into law by the President as the Internal Revenue Code of 1954. Over a year and a half of intensive study, staff work, hearings, debates, and finally drafting, went into the revision of the Internal Revenue Code. The announced objectives of this revision were: to conform the federal tax structure with the long-range economic requirements of the nation, to eliminate inequities which had developed over the years, and to simplify compliance and administration. These are highly worthy objectives, the achievement of which, presumably, would have settled demands for tax reform. However, as we all know, the last year has witnessed ever-increasing attacks on the federal revenue system, focused primarily on the income tax. These criticisms have centered on the high level of rates, the effect of the tax structure on individual and business incentives, the opportunities for avoidance, and the resulting increased emphasis on tax considerations which affect management decisions, on the complexity of the law - in short, on the Internal Revenue Code of 1954, and its deficiencies in terms of economic consequences, fairness, administration and compliance.

\footnotetext{
†Based upon a speech delivered before the Taxation Section, American Bar A'ssociation, August 25, 1956, Dallas, Texas.

* Member of Congress, 2d Dist., Arkansas; A.B., Hendrix College; LL.B., Harvard School of Law; member House Committee on Ways and Means, Joint Committee on Internal Revenue Taxation; Joint Economic Committee, and Joint Committee on Reduction of NonEssential Federal Expenditures; chairman Subcommittee on Internal Revenue Taxation of the Committee on Ways and Means.
} 
Much of this criticism is completely irresponsible and negative; nevertheless, we are all aware that there is a pressing need for a thorough study of the substantive policy, technical adequacy and administration of our internal revenue laws.

It has been stated that the Internal Revenue Code of 1954 represents the loss of a legislative opportunity. It is submitted that this is not so. On the contrary, the new Code contains major improvements and represents a long step forward on the road towards a complete overhaul of our internal revenue system. Yet, no serious student of our fiscal processes can believe that even as an elaborate undertaking as the 1954 Code settles once and for all the enormous range of issues inherent in our system of taxation, a system which produces over sixty-eight billion dollars in net revenue in but a single year. This is particularly true because in many important respects the "new Code" is not new.

Many of the members of the Ways and Means Committee are concerned about the economic impact of many of the provisions of the 1954 Code. The flood of critical mail received by the members of this committee and the Senate Finance Committee, the deluge of amendments dropped into the legislative hopper, the torrent of almost hysterical articles appearing in periodicals and the public pronouncements of those who would abolish our income tax entirely all testify to the fact that there are still serious inequities and deficiencies in the statute. Complexity, of course, remains one of the outstanding characteristics of the Code. A cursory examination of the technical articles written by members of the bar for publication in tax and legal journals testifies to the fact that many tax specialists have grave doubts as to the technical adequacy and underlying substantive policy of many of the provisions of the "new law."

In addition to having to cope with a "new" Code, the tax bar, tax accountants and the tax-paying public have had to contend with the new administrative organization undertaken under Reorganization Plan No. 1. Recognizing that the effectiveness of the Internal Revenue Code depends in large part on the machinery for translating tax law into collected revenues, many are concerned about the changes made not only in the administrative organization of the Internal Revenue Service, but in the methods of functioning which have been made in the process under Reorganization 
Plan No. 1. To the extent these changes have affected the service's ability to administer the law fairly and effectively, there is cause for concern. In this field the tax-writing committees of Congress have a duty to fulfill which can be satisfied only by an appraisal undertaken after an objective study designed to develop the facts and statistics on which to predicate judgment.

Briefly then, the establishment of the Subcommittee on Internal Revenue Taxation reflects recognition of the fact that a project as broad in compass and impact as the Internal Revenue Code of 1954 requires close review at this, the earliest date upon which an objective basis for its evaluation exists. The Subcommittee was established in a spirit of searching, constructive appraisal and criticism. Its objective is to build upon the present, to attain the best possible tax law and to establish a precedent in the revision of the nation's tax system based on a non-partisan and appropriately objective approach.

\section{SCOPE OF INQUIRY}

As has been indicated, it is contemplated that the Subcommittee's work will have two major aspects: one will involve a technical study and investigation of the substantive policy and technical adequacy of the statute, and the other will be concerned with the administration and enforcement of our tax laws.

The Subcommittee's life necessarily can be no longer than that of the Congress in which it was created. It is anticipated, however, that the Subcommittee will be reconstituted in the new session of Congress. Because of the limited time available before the expiration of the Eighty-Fourth Congress, however, it was necessary that efforts be concentrated on a limited study of the matters coming within the Subcommittee's jurisdiction in order that a report might be made to the Committee on Ways and Means before the first of the year. Accordingly, the members of the Subcommittee unanimously agreed to limit the scope of the inquiry to reviewing the new provisions of the Internal Revenue Code of 1954 and those provisions carried over into it without substantive change to determine what technical and substantive corrections and changes were immediately necessary. This review has been primarily concerned with technical and clerical errors, ambiguities, with instances in which unintended hardships are imposed upon taxpayers, and with instances in which unintended advantages are given to taxpayers. 


\section{Regulations}

The Subcommittee has also studied the correlation between the statute and the implementing regulations promulgated thereunder to determine the extent of uniformity in substantive meaning and presence of clarity. It should be pointed out, however, that the Subcommittee has no intention of establishing itself as a board of post-review for the regulations program, nor does it have any intention of lending itself to those who desire a forum before which to revive the voluminous protests filed with the Treasury Department in connection with the regulations issued under the 1954 Code.

The Taxation Section of the American Bar Association at one time considered recommending that all proposed regulations be reviewed by the Joint Committee on Internal Revenue Taxation. This proposal, however, never achieved the dignity of an official proposal of the Tax Section of the American Bar Association. In those instances in which the regulations are vulnerable, the power lies with the courts to deny them the force and effect of law, but neither the courts nor the Congress have the power to rewrite the regulations. It is the Constitutional prerogative of Congress not to change the regulations through some post-review agency, but to change the law.

Nevertheless, there are certain areas where the new regulations are imperfect and vulnerable. The cause of this vulnerability in most of the cases is an imperfect statute which has required the Treasury Department to take extreme positions for the protection of the revenues. Obviously, it is to the advantage of both the taxpaying public and of the Treasury Department to have the statute perfected in these areas rather than to leave the matter to litigation and its inevitable uncertainties. In the past both the Treasury Department and taxpayers have suffered irreparable damage because a regulation of longstanding acceptance has been overturned by the courts. When this happens, those taxpayers who have accepted the regulation and relied upon its terms have been placed in a disadvantageous position compared to their more litigious brothers, and the Treasury Department has been confronted with retroactive claims for all open years. To the end of avoiding the necessity for such litigation and its accompanying pitfalls and inequities, the Subcommittee has and will continue to receive the co-operation of 
the Treasury Department in pointing out those areas where the statute should be changed and new regulations issued.

\section{Administration of the Code}

The Subcommittee has also inquired into the administration of the internal revenue laws under the Reorganization Act of 1951. Some work in this field has already been done by an advisory group at the direction of the Joint Committee on Internal Revenue Taxation.

Many of the recommendations of this advisory group have been accepted and put into effect by Commissioner Harrington. The Subcommittee has reviewed the report of this advisory group and made such other inquiries as are necessary to develop the facts and statistics on which to base an objective appraisal of the operation of the Internal Revenue Service under the Reorganization Act of 1951.

The reorganization plan was not unanimously endorsed by the Congress. The functioning of the Service has been a matter of continuing concern as the plan has been put into effect. The basis of this concern lies in the record of decreasing collections of back taxes and increasing amounts of taxes outstanding for which warrants have been issued. It lies also in mounting evidence of declining morale in the Service and a general worsening of enforcement achievements. The emphasis on decentralization in the organization, while conveying some advantages, has also involved major liabilities evidenced by a lack of uniformity in interpretation and application of the laws, regulations and rulings, as well as in a reluctance to make and take the responsibility for settlements.

It should be pointed out that the objective of the Subcommittee in the administrative area is not to shake the Internal Revenue Service by its heels, nor to make headlines. On the contrary, its purpose is an objective appraisal of the present administrative organizations and practices to determine whether our tax laws are being enforced as effectively, efficiently and fairly as possible, and to determine what statutory changes are necessary in order to correct any difficulties discovered.

It would be well if a personal relationship could be established between the members of the Subcommittee and the officials of the Treasury Department and Internal Revenue Service. Through such a relationship, it would be possible to establish a rapport making for a better congressional understanding of the problems confronted 
by officials of the Treasury Department and the Internal Revenue Service in the every day performance of their duties.

It should be possible for officials of the Treasury Department, the Internal Revenue Service, and members of the tax-writing committees of Congress to sit down and discuss their mutual problems in a spirit of co-operation and mutual understanding. Only when this is done will the mutual apprehension with which the Treasury Department and the tax-writing committees of Congress have viewed each other in recent years under administrations of both parties disappear, and only then can taxpayers be assured that they are paying taxes under the best system of taxation obtainable.

It is submitted that Congress should supply more incentives to officials in the Treasury Department and the Internal Revenue Service. It is unfortunate that the best of our young tax lawyers and tax economists have come to regard the Internal Revenue Service as a training school to be left as soon as their professional pinfeathers have been developed. The Subcommittee must think long and hard upon ways and means of securing and keeping men of the same caliber in the Internal Revenue Service as private clients and interests expect and demand to represent them.

The author does not mean to imply that there are not now men of the highest professional attainments in the Internal Revenue Service. This is far from true, but every day these men must ask themselves whether or not the rewards of their public service are commensurate with the heavy burdens that they must carry. Surely, these men must occasionally think that their tasks are unrewarded. Every day they are confronted with problems of a magnitude that the private practitioners never know. They are damned on all sides. Accordingly, it is believed that members of the Subcommittee will see to the establishment of a policy which will assure officials of the Treasury Department and the Internal Revenue Service that the tremendous problems which they face are understood, that the job which they are doing is appreciated, and will provide the rewards necessary to obtain and hold men in the Service of a caliber equal to, if not higher than, that of their opposite numbers in the outside business world.

\section{Examination of the Code}

A number of substantive areas exist in which the 1954 Code made little if any significant change in the provisions of the old law. In some cases this was intentional. For example, President Eisen- 
hower listed several areas with respect to which suggestions for revision were deferred pending further administrative study in his budget message of January 21, 1954. Among these were the tax treatment of capital .gains, co-operatives, tax-exempt institutions, and retirement income for persons not covered by pension plans. In other cases proposed revisions which passed the House of Representatives died in the Senate. Examples are the tax treatment of income derived from abroad, deferred compensation plans, and income from the cancellations of indebtedness.

The fact that the new Code has not substantially altered the 1939 Code in these areas has, of course, left unresolved pressing substantive issues. Indeed, many of these issues have been brought into sharper focus by virtue of changes elsewhere in the Code. For example, the accelerated depreciation methods incorporated in Section 167 have changed the perspective in which the revenue consequences, the economic impact and equity considerations of Section 1231 -old Section $117(\mathrm{j})$-must be viewed. A major order of business for the Subcommittee on Internal Revenue Taxation, therefore, will be to cover ground not adequately or successfully explored in the 1954 revision.

Apart from the substantive areas passed over in the 1954 Code, there are a number of questions of substantive policy in new statutory provisions which call for searching review and study. Among the more pressing of these are the provisions of Subchapter C, particularly with respect to the transferability of loss carryovers.

The 1954 grant of a dividends exclusion and credit for individuals has clearly not provided an adequate integration of the individual and corporate income taxes. Indeed, the operation of the dividends received credit for individuals on the alternative computation of capital gains will have created a first class loophole in the law if the Treasury's regulations are overturned. Whether or not the dividends exclusion and credit for individuals are viewed from the point of view of the proponents who base their arguments upon the premise of double taxation, or from the point of view of those who were concerned primarily with the impact of the tax on corporate financial structure and policies, little objective evidence can be found that the 1954 provisions are the appropriate answers.

Similarly, the trust and partnership provisions of the 1954 Code should be closely examined. The problem of multiple trusts is a growing one which, taking into consideration the accumulation pro- 
visions of Subchapter $\mathrm{J}$, requires attention. The partnership provisions of the Code, while representing technical improvement, are, nevertheless, so complex that our small entrepreneurs are finding it necessary to abandon more and more of their business decisions to their tax advisers. As a matter of fact an ever-increasing number of partnerships are being advised to incorporate because of the complexities in Subchapter $\mathrm{K}$ and the attendant uncertainty which such complexities create.

The estate and gift tax provisions require substantial modifications. These taxes suffer from a lack of perspective as to their function in the over-all framework in our revenue system. They do not serve the basic purpose of a tax since they produce little revenue. Indeed, their only purpose seems to be to encourage taxpayers to find increasingly more tortuous ways in which to dispose of their property.

\section{Criteria to be Employed}

The end product of a substantive inquiry of the magnitude which the Subcommittee hopes to ultimately carry out will depend primarily on the criteria employed.

One of the principal standards against which to measure tax provisions is fairness. Admittedly, it is difficult to formalize equity in specific terms. However, all are aware of the vast extent of discrimination that has invaded the tax law. We have lost sight of the need for uniformity in our income tax, the principal source of the government's revenues, in continuing attempts to equalize preferential treatment. There is increasing recognition of the dangers inherent in this process. Where special tax provisions reflect more than basic economic differentials, the taxpaying public soon becomes aware, even though only in vague terms, of the resulting disparities in tax treatment. The consequent lack of confidence in the fairness of the law represents a serious threat to its enforceability, which in turn endangers the nation's fiscal strength and stability.

As a corrollary to the equity standard, the rule of uniformity is also meaningful in a second important criterion: that tax provisions minimize distortions in economic activity. As evidence of the weaknesses and crises of collectivist economies are becoming increasingly apparent, particularly in eastern Europe, we gain an ever-increasing appreciation of the strength and effectiveness of our free-market, private enterprise system. We also recognize, however, that when government activities account for close to a fifth of our national 
income, the tax system which finances those activities may have significant consequences for the non-government sector of the economy. If our enterprise system, operating through the impersonal price mechanism in free markets, is to assure the most efficient use of our economic resources, we must be sure that tax considerations do not counteract the market place's signals to consumers, investors, and managers. Special tax provisions, however, often introduce considerations which are at variance with the signals of the market place. If the benefits from these special tax provisions are great enough, they may-in fact, they do today-often outweigh market considerations. The result will be, and is, interference in the use of resources and, therefore, a lower total real value for the product of the economy.

We must recognize how great a responsibility is assumed in providing preferential tax treatment. These provisions represent value judgments about the type of economic activity most essential to the process of economic growth. This is the very type of decision which cannot be safely made except by the impersonal mechanism of the price system.

The criteria of equity and of neutrality in economic impact are closely allied to that of maximizing the responsiveness of government revenues to broad changes in economic conditions. The study last fall by the Joint Economic Committee's Subcommittee on Tax Policy served to develop the importance of a cyclically sensitive tax system in avoiding both inflation and recession which disrupt steady economic growth and development. Those responsible for fiscal policy, both in the Administration and the Congress, cannot, of course, ignore the fact that changes in tax rates may be necessary to insure that the federal budget will interfere as little as possible with the steady growth of the economy. But to the extent that the tax system contains features which respond automatically to changes in the over-all level of economic activity, serving to damp down inflationary pressures and to cushion recession movements, the need for explicit compensatory fiscal and monetary action is reduced.

The principal limitations on this built-in flexibility in our revenue system stem from the wide range of special provisions which shelter cyclically-sensitive types of income from ordinary income tax treatment. Adherence to the standards of fairness and of minimizing economic distortions, therefore, would also serve to increase the responsiveness of our tax system to changes in economic conditions. 
The criteria of simplicity and ease of administration of the tax laws are similarly related to the basic standards of fairness and of economic neutrality. The present complexity of the Internal Revenue Code and the most difficult problems of administration are traceable, in large part, directly to provisions which provide exceptions to broad rules. It is evident that we cannot have a simpler tax law unless we have a fairer, more neutral, and more responsive tax system.

That these criteria have been too often ignored in past legislative revisions of our internal revenue laws is demonstrated by the extent to which both the base and rate structure of our income tax has been eroded. This erosion is not only felt in a loss of progression but in the uneven impact of our tax rates upon individuals in the same tax group. As a result, our tax system is failing to do equity in the sense of equal treatment of persons with equal income. Discriminations exist not only between broad classes of taxpayers but between types of income, with earned income the loser in a battle between proponents of a tax policy which is designed to encourage investment and proponents of a tax policy which is designed to encourage consumption.

Tax attorneys are all too familiar with the reasons why most of our high income taxpayers do not pay income taxes at the rates appearing in the schedules of Section 1 of the Internal Revenue Code. It is their business to know and understand the use of every tax shelter accorded by our internal revenue laws. The doctrine of United States $v$. Isham, ${ }^{1}$ even though it was decided in another century, justifies reliance upon the platitude that taxpayers have the right to avoid taxes if they confine themselves to the means that are legal to that end. After all, Congress has written the law. But what is the effect of the existence of these tax preferences? How do they effect the morale of our taxpayers? What will continuation of the erosion of the tax base do to the fiscal integrity of our nation? And with what will we replace the income tax when it is ultimately destroyed by a withdrawal of public confidence?

Many distinguished and learned members of the tax bar have made lists of the tax preferences which they believe are responsible for the erosion of our tax base. Most of these lists include the follcwing: the exemption of interest upon state and local government bonds; the deductions for percentage depletion and expenses of ex-

\footnotetext{
${ }^{1} 84$ U.S. 496 (1873).
} 
ploration and development of mineral resources; the special tax treatment accorded co-operatives, foundations, and charitable organizations; the exemption of interest upon savings invested in life insurance; the deductibility of personal consumption expenditures; income-splitting between husband and wife, by the use of multiple trusts, gifts inter vivos, and family partnerships; the sanction given by the Code to deferred compensation arrangements, pension trusts and stock options; and last, but never least, the preferential treatment given by the Code to capital gains in all its multitudinous and artificial forms. With respect to these tax preferences, or, if you will, "differentials," presently accorded by the statute, the Subcommittee is aware that in the universe of discourse of taxation what is to one man a "loophole" is to another but the cure of an "inequity," and that there exist areas within the realm of tax policy where a tax preference may be legitimately accorded because of the needs of the economic and social welfare of our nation. And, while each and every one of those groups in our taxpaying public who today enjoys a tax preference of one kind or another believes that its particular preference falls in this category, the time for a re-examination of each and every preference is at hand. Those which can be justified can be retained. Those which are not justified by the facts, objectively considered, should be repealed. Only when this is done will it be possible for us to accomplish the thing which we all desire-a reduction in rates and the restoration of equity and true progressivity in our rate structure.

\section{CONCLUSION}

The success or failure of the Subcommittee on Internal Revenue taxation will depend in large measure upon the extent to which the members of the tax bar carry out their responsibilities to the public. This group, along with those accountants and economists who are best qualified in terms of study and experience to help in the work which the Subcommittee is undertaking, is invited to devote its best efforts to the construction of a better revenue system.

Too often in the past, members of the tax-writing committees of Congress have found in the recommendations of the American Bar Association evidence of self pleading, which, in all fairness, should have been presented for what they were, that is, advocacy of a particular client's interest, as distinguished from that disinterested and thoughtful aid which the members of those committees and 
the public are entitled to have from the organized bar. Documentary substantiation that this is true is made unnecessary by the prevalence of the pracitce.

The members of the tax bar are particularly well-equipped with a knowledge of what is wrong with our tax law and tax policy, and with what may be done to cure existing defects and to create a statute best suited to raise the revenues needed for the support of our government, and for the continued growth, stability and protection of our economy. 